Eur J Clin Chem Clin Biochem

1995; 33:687-691

(c) 1995 Walter de Gruyter \& Co. Berlin · New York

\title{
Granulocyte-Monocyte Colony Forming Unit Content of Autologous Bone Marrow Transplants in Patients with Haematological Malignancy
}

\author{
By Mladen Petrovečki ${ }^{1}$, Damir Nemet ${ }^{1}$, Tatjana Kolevska ${ }^{2}$ and Matko Marušić \\ ${ }^{1}$ Department of Immunology of the Institute of Clinical Laboratory Diagnosis and Department of Haematology; \\ Zagreb University Hospital and School of Medicine, Zagreb, Croatia \\ 2 Department of Internal Medicine, "Holy Spirit" General Hospital, Zagreb, Croatia
}

(Received January 23/April 10, 1995)

Summary: Cell viability and number of granulocyte-monocyte colony forming units (CFU-GM) were systematically assessed in 57 patients who had undergone transplantation of the autologous bone marrow for treatment of haematologic malignancies. Bone marrow cell cultivation in agarose with feeder layers appeared inferior to that performed in agarose with recombinant human granulocyte-monocyte colony stimulating factor and methylcellulose with phytohaemaglutinin leukocyte-conditioned medium. Since the transplant cells were frozen in liquid nitrogen between harvesting and reinfusion, the following samples were tested: buffy coat cells, buffy coat cells immediately after addition of dimethylsulphoxide, cell sample that had been frozen for 24 hours, and frozen transplant cells at the time of thawing and transplantation. Each procedural step decreased both cell viability and the number of CFU$\mathrm{GM}$, but since the lymphohaematologic recovery in all patients followed the pattern reported in the literature for high-quality transplants, we concluded that our transplants retained the necessary number of progenitor cells. It appears that the best strategy for dynamic assessment of the transplant quality would be to perform tests after every step of the transplant processing. Cell viability and number of progenitors per body weight in transplants were also found to be associated with probability of neutrophil reconstitution after bone marrow reinfusion.

\section{Introduction}

Autologous bone marrow transplantation is a modern and powerful method for treatment of haematological and non-haematological malignancies (1). However, the methods for bone marrow harvesting, freezing and storing $(2,3)$, as well as laboratory methods for assessing the number of granulocyte-monocyte/macrophage colony forming units (CFU-GM) in the transplants (4) vary substantially in different transplantation centres. Although the pluripotent stem cell is responsible for lymphohaematopoietic recovery of a patient, the committed progenitor cell grown in vitro (CFU) is strongly related to the posttransplantation recovery of blood cell populations (2) and is thus used for estimation of the transplant quality. Its content in the transplant mostly affects the numbers of leukocytes and neutrophils $(5,6)$, but also the numbers of lymphocytes and platelets $(1,7)$ in the post-transplantation time period.

Since there is still no worldwide standardized in vitro technique for CFU-GM cultivation, the choice of method depends on laboratory practice, i.e. available technologies, reproducibility and training. It has been suggested that each routine clinical laboratory should have its own standard (8).

The aim of this investigation was an evaluation of the CFU-GM content and cell viability characteristics of bone marrow transplants during their preparation for transplantation. Since 1988, our team has performed a number of autologous bone marrow transplantations (9), and the resulting data has enabled us to define the most rational scheme for the procedure and our respective lab- 
oratory standards. The results of our investigation were improved by relating the laboratory test results of the bone marrow transplants to the posttransplantation haematological recovery of neutrophils in peripheral blood of the patients.

\section{Patients and Methods}

\section{Patients}

The study was performed on 57 bone marrow samples from patients undergoing autologous transplantation in the period from March 1988 to July 1993. All had haematological malignancy: 30 acute myeloid leukaemia, 19 acute lymphoid leukaemia, five Hodgkin's disease and three non-Hodgkin lymphoma. There were 33 males and 24 females, median age of 24 years (range 2 to 54). Patients were consolidated with high or intermediate doses of cytosine-arabinoside. Three protocols were used for complete myeloablative therapy before transplantation:

(a) total body irradiation (12 Gy, fractionate) after cyclophosphamide $2 \times 60 \mathrm{mg} / \mathrm{kg}$ body weight $(\mathrm{N}=32,56.1 \%$ of the patients),

(b) cyclophosphamide $2 \times 60 \mathrm{mg} / \mathrm{kg}$ and busulphan $4 \times 4 \mathrm{mg} / \mathrm{kg}$ body weight $(\mathrm{N}=18,31.6 \%)$, and

(c) (BEAM) scheme $\left(\mathrm{N}=7,12.3 \%\right.$ ). BCNU $1 \times 300 \mathrm{mg} / \mathrm{m}^{2}$, ethoposide (VP16-213) $4 \times 200 \mathrm{mg} / \mathrm{m}^{2}$, ara-C $8 \times 200 \mathrm{mg} / \mathrm{m}^{2}$ and melphalan $1 \times 140 \mathrm{mg} / \mathrm{m}^{2}$. The first two protocols were used for all malignancies, and the third one for lymphomas only.

\section{Methods}

Buffy coat was prepared from bone marrow on a COBE 2991 Blood Cell Processor, chilled on ice to $4^{\circ} \mathrm{C}$, mixed with dimethylsulphoxide (volume fraction 0.1 ) as cryoprotective agent at the same temperature, frozen using a controlled freezing system and stored in liquid nitrogen at $-196^{\circ} \mathrm{C}$. Cell viability and clonogeneic activity were tested in three preparation steps before transplant reinfusion (buffy coat, buffy coat immediately after addition of dimethylsulphoxide, and buffy coat plus dimethylsulphoxide 24 hours after freezing), and in a transplant sample at the time of reinfusion.

Mononuclear cells were prepared from the buffy coat by gradient separation $(1.077 \mathrm{~kg} / \mathrm{l})$ and washed twice in RPMI-1640 medium (Immunology Institute, Zagreb, Croatia). Samples with dimethylsulphoxide were slowly diluted immediately after thawing $1: 10$ with medium containing 0.01 volume fraction of $L$-glutamine ( $L$ glutamine $200 \mathrm{mmol} / \mathrm{l}$, Gibco, Paisley, UK) and 0.1 volume fraction of fetal calf serum (Gibco). Cell viability was tested by the trypan blue exclusion method (Trypan blue $0.4 \%$, Sigma, USA). Clonogeneic activity was assessed using three methods. For 33 samples, $10^{5}$ mononuclear cells were mixed with medium containing fetal calf serum and agar (final volume fractions 0.1 and 0.03 , respectively) in a volume of $1 \mathrm{ml}$, then layered over a 5 to 10 day-old feeder layer prepared from healthy donor leukocytes (10). Cultivation on feeder layers was always done in parallel with a control sample containing a known number of progenitors; if the number of CFU-GM in the control was $10 \%$ less or greater than expected, the feeder layer was replaced with a new one. For 9 samples, $10^{5}$ mononuclear cells were resuspended in medium containing the same quantities of fetal calf serum and agar, anid $250 \mathrm{ng}$ of recombinant human granulocyte-monocyte colony stimulating factor (GM-CSF) in $1 \mathrm{ml}$ final volume (GMC 89-107, Sandoz Pharma AG, Basel, Switzerland). For the remaining 15 samples, $5 \times 10^{4}$ mononuclear cells were mixed with $0.5 \mathrm{ml}$ of commercially prepared medium (MethoCult H4432, StemCell Technologies Inc, Vancouver, Canada) containing methylcellulose, phytohaemagglutinin leukocyte-conditioned medium (volume fraction $0.1)$ and $3 \times 10^{3} \mathrm{U} / 1$ of recombinant human erythropoietin (11).
For all methods, plating was done in triplicate and the average number of CFU-GM was calculated.

\section{Data analysis}

All the data are numerical. They are presented with the median value, and the 10th to 90 th percentile range, because all values except cell viability were not normally distributed. The differences between groups were tested using the Wilcoxon test for matched pairs and Kruskal-Wallis non-parametric analysis for several group means.

The probable time of haematopoietic engraftment was taken as the posttransplantation day on which the neutrophil counts in the peripheral blood reached values of $0.2 \times 10^{5} / 1$ and $0.5 \times 10^{5} / 1$ respectively, as calculated and constructed by the Kaplan-Meier method of incomplete observation. Patients were censored if they did not attain the count by the last day of the follow up. The influence of various laboratory conditions on the engraftment kinetics was assessed by using Cox's forward stepwise multivariate regression analysis. The following variables were analysed: transplant volume, total number of mononuclear cells, number of mononuclear cells per transplant volume and per body weight, cell viability, total number of CFU-GM, and number of CFU-GM per $10^{5}$ mononuclear cells and per body weight. All reported p-values referred to two-sided tests, and were considered significant if less then 0.05 .

\section{Results}

For each transplant, samples in four different steps of preparation were analysed: buffy coat cells after ficoll separation, buffy coat cells immediately after addition of dimethylsulphoxide, the cells that had been frozen at least 24 hours, and the cells from the frozen transplant at the day of transplantation. Average cell viability and number of CFU-GM in the samples are presented in table 1. After each procedural step, the viability of cells was significantly lower, except between the first two samples (buffy coat and buffy coat with dimethylsulphoxide). Similarly, the number of the CFU-GM was significantly lower after each procedural step except for the difference between samples with dimethylsulphoxide before and $24 \mathrm{~h}$ after freezing (tab. $1, \mathrm{p}<0.05$ ).

Table 2 presents the number of CFU-GM according to laboratory method used for stimulation of the growth of bone marrow cells in the culture: feeder layers, agarose with recombinant human GM-CSF, methylcellulose with phytohaemagglutinin leukocyte-conditioned medium. There was no significant difference in CFU-GM content in relation to the cultivation method, although, compared with the other two techniques, values obtained with cells from the fresh buffy coat were considerably lower if feeder layer was used (tab. 2, 40 compared with 50 and 51 CFU-GM per $10^{5}$ mononuclear cells). In general, however, the data showed the same pattern of decreasing CFU-GM values as described in table 1, i. e. lower numbers of the CFU-GM after each step of the processing of the transplant.

We also investigated CFU-GM content according to the type of malignancy and therapy, 'as reported in the $\mathrm{Pa}$ - 
Tab. 1 Cell viability and number of granulocyte-monocyte colony forming units (CFU-MG) in bone marrow samples of patients with haematological malignancy, prepared for autologous bone marrow transplantation

\begin{tabular}{|c|c|c|c|c|c|}
\hline \multirow[t]{2}{*}{ Transplant sample } & \multicolumn{2}{|c|}{ Cell viability } & \multicolumn{3}{|c|}{ p-values } \\
\hline & Median & $\begin{array}{l}\text { 10th-90th } \\
\text { percentile range }\end{array}$ & B & $\mathrm{C}$ & $\mathrm{D}$ \\
\hline \multirow[t]{3}{*}{$\begin{array}{l}\text { A - Buffy coat } \\
\text { B - Buffy coat }+ \text { dimethylsulphoxide } \\
\text { C - Buffy coat frozen }>24 \text { hours } \\
\text { D - Sample at the time of reinfusion }\end{array}$} & $\begin{array}{l}95 \\
94 \\
88 \\
86\end{array}$ & $\begin{array}{l}88-99 \\
90-99 \\
81-93 \\
77-94\end{array}$ & $\begin{array}{l}\text { NS } \\
- \\
- \\
-\end{array}$ & $\begin{array}{l}<0.01 \\
<0.01 \\
- \\
-\end{array}$ & $\begin{array}{l}<0.01 \\
<0.01 \\
<0.05 \\
-\end{array}$ \\
\hline & \multicolumn{2}{|c|}{$\begin{array}{l}\text { No. of CFU-GM per } 10^{5} \\
\text { mononuclear cells }\end{array}$} & \multicolumn{3}{|c|}{ p-values } \\
\hline & Median & $\begin{array}{l}\text { 10th }-90 \text { th } \\
\text { percentile range }\end{array}$ & B & $\mathrm{C}$ & D \\
\hline $\begin{array}{l}\text { A - Buffy coat } \\
\text { B - Buffy coat }+ \text { dimethylsulphoxide } \\
\text { C }- \text { Buffy coat frozen }>24 \text { hours } \\
D-\text { Sample at the time of reinfusion }\end{array}$ & $\begin{array}{l}45 \\
37 \\
34 \\
27\end{array}$ & $\begin{array}{l}20-98 \\
18-64 \\
14-77 \\
14-60\end{array}$ & $\begin{array}{l}<0.01 \\
- \\
-\end{array}$ & $\begin{array}{l}<0.01 \\
\text { NS } \\
- \\
-\end{array}$ & $\begin{array}{l}<0.01 \\
<0.01 \\
<0.05 \\
-\end{array}$ \\
\hline
\end{tabular}

p-values represent probabilities derived from testing the differences of viability and CFU-GM numbers between procedural steps during the preparation of buffy coat; letters $B, C$ and $D$ designate transplant samples defined in the first column of the table. NS not significantly different $(p>0.05)$.
Tab. 2 Number of granulocyte-monocyte colony forming units (CFU-GM) in bone marrow samples of patients with haematologi- cal malignancy, prepared for autologous bone marrow transplantation according to the cultivation methods

Transplant sample

No. of CFU-GM per $10^{5}$ mononuclear cells stimulated with

\begin{tabular}{|c|c|c|c|c|c|c|c|}
\hline & \multirow{2}{*}{\multicolumn{2}{|c|}{$\begin{array}{l}\text { Feeder layer } \\
(\mathrm{N}=33)\end{array}$}} & & & & & \\
\hline & & & \multicolumn{2}{|c|}{$\begin{array}{l}\text { Recombinant } \\
\text { human GM-CSF } \\
(\mathrm{N}=9)\end{array}$} & \multicolumn{2}{|c|}{$\begin{array}{l}\text { Phytohaemagglutinin leuko- } \\
\text { cyte-conditioned medium } \\
(\mathrm{N}=15)\end{array}$} & \\
\hline & Median & $\begin{array}{l}10 \text { th }-90 \text { th } \\
\text { percentile range }\end{array}$ & Median & $\begin{array}{l}\text { 10th }-90 \text { th } \\
\text { percentile range }\end{array}$ & Median & $\begin{array}{l}\text { 10th }-90 \text { th } \\
\text { percentile range }\end{array}$ & \\
\hline Buffy coat & 40 & $19-95$ & 50 & $17-114$ & 51 & $44-98$ & 0.057 \\
\hline $\begin{array}{l}\text { Buffy coat }+ \text { dimethyl- } \\
\text { sulphoxide }\end{array}$ & 33 & $18-75$ & 40 & $12-60$ & 42 & $23-62$ & 0.540 \\
\hline $\begin{array}{l}\text { Buffy coat frozen } \\
>24 \text { hours }\end{array}$ & 28 & $14-65$ & 44 & $12-107$ & 39 & $25-73$ & 0.338 \\
\hline $\begin{array}{l}\text { Sample at the time } \\
\text { of reinfusion }\end{array}$ & 25 & $15-45$ & 21 & $10-88$ & 33 & $20-55$ & 0.408 \\
\hline
\end{tabular}

p-values represent probabilities derived from testing the differences of CFU-GM numbers between all three different cultivation meth- ods using non-parametric analysis of variance.

tients section, but there was no significant difference be= tween respective patient groups (data nọt shown).

In patients presented in this study (fig. 1), a neutrophil count in the peripheral blood of $0.2 \times 10^{5} / 1$ was attained between 7 and 58 days after transplantation (median 14 days, two patients died before achieving the count), and of $0.5 \times 10^{5} / 1$ between 11 and 72 days after transplantation (median 22 days, three patients died before achieving the count). Table 3 presents laboratory values analysed for their influence on the engraftment kinetics of neutrophil cells in peripheral blood of the patients. Only cell viability and number of granulocyte-monocyte pro-

\section{Discussion}

genitors per $\mathrm{kg}$ of body weight were found to be independently and significantly associated with the probability of haematopoietic reconstitution, both determined on the basis of neutrophil concentrations, and with negative correlation coefficients.

Cell viability and number of CFU-GM, together with the total number of mononuclear cells in a bone marrow transplant, are basic indicators of the quality of a transplant, especially if freezing of autologous bone 
Tab. 3 Laboratory characteristics of the transplant samples in relation to engraftment kinetics of the patients treated with autologous bone marrow transplantation

\begin{tabular}{|c|c|c|c|c|c|c|c|c|c|}
\hline \multirow[t]{3}{*}{$\begin{array}{l}\text { Transplant } \\
\text { characteristic }\end{array}$} & \multirow[t]{3}{*}{ Unit } & \multicolumn{2}{|l|}{ Value } & \multicolumn{6}{|c|}{$\begin{array}{l}\text { Influence on the attainment of the number of neutrophils } \\
\text { in peripheral blood after reinfusion }\end{array}$} \\
\hline & & \multirow[t]{2}{*}{ Median } & \multirow{2}{*}{$\begin{array}{l}10 \text { th-90th } \\
\text { percentile } \\
\text { range }\end{array}$} & \multicolumn{3}{|c|}{$\geqslant 0.2 \times 10^{9} /$} & \multicolumn{3}{|c|}{$\geqslant 0.5 \times 10^{9} / 1$} \\
\hline & & & & $\chi^{2}$ & $\mathrm{p}$ & $r$ & $\chi^{2}$ & $\mathrm{p}$ & $\mathbf{r}$ \\
\hline Volume & $\mathrm{ml}$ & 470 & $288-610$ & 0.46 & NS & & 0.09 & NS & \\
\hline $\begin{array}{l}\text { No. of } \\
\text { mononuclear cells } \\
\text { per volume }\end{array}$ & $10^{9} / 1$ & 29.8 & $13.8-48.2$ & 3.54 & NS & & 1.19 & NS & \\
\hline $\begin{array}{l}\text { Total no. } \\
\text { of mononuclear cells }\end{array}$ & $10^{8}$ & 121.5 & $66.9-212.8$ & 0.99 & NS & & 0.02 & NS & \\
\hline $\begin{array}{l}\text { No. of } \\
\text { mononuclear cells } \\
\text { per body weight }\end{array}$ & $10^{8} / \mathrm{kg}$ & 2.02 & $1.26-3.00$ & 0.93 & NS & & 2.50 & NS & \\
\hline Mononuclear viability & $\%$ & 86 & -94 & 4.90 & $<0.05$ & -0.168 & 8.72 & $<0.01$ & -0.234 \\
\hline $\begin{array}{l}\text { No. of } \\
\text { CFU-GM per } 10^{5} \\
\text { mononuclear cells }\end{array}$ & 1 & 27 & $14-60$ & 0.83 & NS & & 2.35 & NS & \\
\hline Total no. of CFU-GM & $10^{6}$ & 3.94 & $1.32-8.29$ & 0.25 & NS & & 0.01 & NS & \\
\hline $\begin{array}{l}\text { No. of CFU-GM } \\
\text { per body weight }\end{array}$ & $10^{4} / \mathrm{kg}$ & 6.29 & $2.46-15.44$ & 3.99 & $<0.05$ & -0.201 & 4.35 & $<0.05$ & -0.165 \\
\hline
\end{tabular}

The influence of transplant characteristics on the attainment of neutrophil counts was tested using the Cox multivariate test; the results of analyses are presented with $\chi^{2}$-values, corresponding $\mathrm{p}$-values

marrow is utilized. The quality of the sample must always be verified before transplantation, because cryoprotective agents, such as dimethylsulphoxide, and cooling and storing techniques can irreparably damage the cells (12). Procedure-related and method-related decreases in cell viability and progenitor content are expected, but the minimal transplant quality, which will allow a good and fast posttransplantation haematologic recovery, must be both monitored and achieved (fig. 1). Inasmuch as all our patients recovered haematologically within the time period reported as clinically favorable $(1,5,13,14)$, our transplant procedure can be considered as serviceable. Multivariate analysis reported in table 3 revealed that the only significant laboratory factors influencing the delay of neutrophil recovery (presented in fig. 1) are cell viability and progenitor content related to the body weight. This is in accord with some studies $(2,5,6)$, while others have failed to confirm it (15). Only the recovery of neutrophils was studied because these cells mature and differentiate directly from CFUGM progenitors. Low correlation coefficients (table 3) suggest that some other conditions, different from those investigated, were also associated with neutrophil engraftment, and that viability and CFU-GM number cannot be used directly for predicting the day of attaining the desired concentration. However, prediction of posttransplantation recovery was not the aim of the study. We simply wanted to assess the need for a valuable labo- and correlation coefficients $(r)$ for variables that are significantly associated with engraftment kinetic. NS - not significant $(p>0.05)$.

ratory technique for testing the validity of the transplant preparation procedure.

Viability and CFU-GM values shown in tables 1 and 2 are actually used as our laboratory standards of the autologous bone marrow transplant quality. It should also be noted that they do not represent minimal, optimal or maximal values, but rather the values clinically related to good haematologic recovery. Our sub-

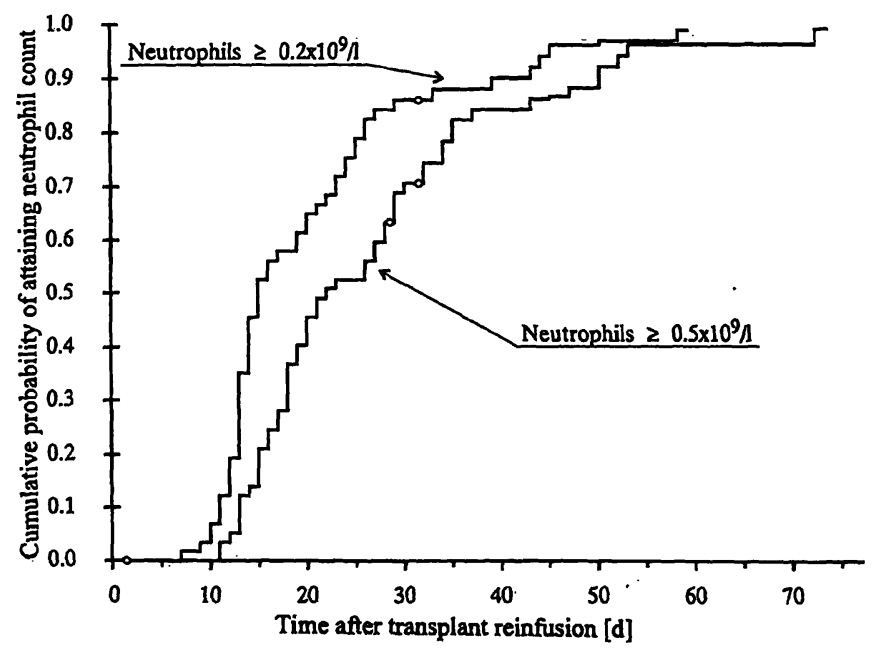

Fig. 1 Cumulative probability of attaining neutrophil counts of $0.2 \times 10^{9} / 1$ and $0.5 \times 10^{9} / 1$ after autologous bone marrow transplantation in 57 patients with haematological malignancy (censored data are indicated with an open circle). 
sequent follow up of 20 new patients (data not shown) revealed the same transplant quality and the same pattern of patient recovery after transplantation, except in one patient whose recovery was very slow and the number of CFU-GM low (11 CFU-GM per $10^{5}$ mononuclear cells in buffy coat).

Although the data did not prove statistically significant, cell cultivation using recombinant human GM-CSF and phytohaemagglutinin leukocyte-conditioned medium in methylcellulose as stimulating factors yielded results that appeared much better than those obtained with feeder layers (tab. 2). The differences were so impressive (tab. 2) that we believe that feeder layers should be avoided if possible, at least for routine laboratory testing. The facility of operation and accuracy of results using completely prepared and standardized media, such as that with phytohaemagglutinin leukocyte-conditioned medium in methylcellulose, support their use over any other technique in the routine laboratory procedures. In addition, the general adoption of such media would permit direct comparison of data from different laboratories, which in turn would allow the introduction of multicentre evaluations.

\section{References}

1. To BL, Roberts MM, Haylock DN, Dyson PG, Branford AL, Thorp D, et al. Comparison of hematological recovery times and supportive care requirements of autologous recovery phase peripheral blood stem cell transplants, autologous bone marrow transplants and allogeneic bone marrow transplants. Bone Marrow Transplant 1992; 9:277-84.

2. Elliott $C$, McCarthy $D$. A survey of methods of processing and storage of bone barrow and blood stem cells in the EBMT. Bone Marrow Transplant 1994; 14:419-23.

3. Gale RP, Reiffers J, Juttner CA. What's new in blood progenitor cell autotransplants? [editorial]. Bone Marrow Transplant $1994 ; 14: 343-6$.

4. Francis GE, Wing MA, Berney JJ. Qualitative differences in the biological activity of two sources of the colony stimulating factor: GCT conditioned medium and leucocyte feeder layers. Exp Hematol 1982; 10:493-8.

5. Lopez M, Mortel O, Pouillart P, Zucker JM, Fechtenbaum J, Douay L, et al. Acceleration of hemopoietic recovery after autologous bone marrow transplantation by low doses of peripheral blood stem cells. Bone Marrow Transplant 1991; $7: 173-81$

6. Rowley SD, Piantadosi S, Marcellus DC, Jones RJ, Davidson NE, Davis JM, et al. Analysis of factors predicting speed of hematologic recovery after transplantation with 4-hydroperoxycyclophosphamide-purged autologous bone marrow grafts. Bone Marrow Transplant 1991; 7:183-91.

7. Spitzer G, Verma DS, Fisher R, Zander A, Vellekoop L, Litam $\mathrm{J}$, et al. The myeloid progenitor cell - its value in predicting hematopoietic recovery after autologous bone marrow transplantation. Blood 1980; 55:317-23.

8. Abrams RA, Polacek L, Buck P. Postcryopreservation growth of human CFU-GM: sequential examination of methodologic factors. Exp Hematol 1985; 13:1089-93.

9. Nemet D. Autologous bone marrow transplantation: a new approach to the treatment of malignant haematological diseases.
Some centres for monitoring transplant quality use methods for CFU-GM cultivation before freezing, some after freezing and some before and after as a standard (2). We feel that the best strategy of a dynamic assessment of the transplant quality would be to perform standardized tests after every step, using any chemical or physical procedure, i. e. in fresh samples before and after adding cryoprotective agent, in the sample stored in liquid nitrogen, and finally in a transplant sample at the time of reinfusion. With this type of laboratory routine, any patient can be individually evaluated (values after the procedure related to values before the procedure), as well being compared with any other patient analysed for cell progenitor content and cell viability in the same or any other clinical laboratory.

\section{Acknowledgements}

This study was supported in part by the Croatian Ministry of Science and Technology, grant No. 3-01-251/91. The authors are grateful to Ms. Maja Rupčić and Žaklina Ćavar for their excellent technical assistance.

Part II: Clinical results in acute leukemias, malignant lymphomas and solid tumors. Liječ Vjesn 1990; 112:53-8.

10. Pike BL, Robinson WA. Human bone marrow colony growth in agar-gel. J Cell Physiol 1970; 76:77-84.

11. Sutherland HJ, Eaves AC, Eaves CJ. Quantitative assays for human hemopoietic progenitor cells. In: Gee AP, editor. Bone marrow processing and purging. Boca Raton: CRC Press Inc, 1991:155-71.

12. Davis JM, Rowley SD. Autologous bone marrow graft processing. In: Sacher RA, McCarthy LJ, Smith Siblinga CT, editors. Processing of bone marrow for transplantation. Arlington: American Association of Blood Banks, 1990:41-62.

13. Douay L, Gorin NC, Mary JY, Lemarie E, Lopez M, Najman A, et al. Recovery of CFU-GM from cryopreserved marrow and in vivo evaluation after autologous bone marrow transplantation are predictive of engraftment. Exp Hematol 1986; 14:358-65.

14. Brandwein JM, Callum J, Sutcliffe SB, Scott JG, Keating A. Analysis of factors affecting hematopoietic recovery after autologous bone marrow transplantation for lymphoma. Bone Marrow Transplant 1990; 6:291-4.

15. Pendry $\mathrm{K}$, Alcorn MJ, Burnett AK. Factors influencing haematological recovery in 53 patients with acute myeloid leukaemia in first remission after autologous bone marrow transplantation. Br J Haematol 1993; 83:45-52.

Maden Petrovečki, M.D., Ph.D.

Department of Immunology

Institute of Clinical Laboratory Diagnosis

Zagreb Clinical Center Rebro

Kišpatićeva 12

41000 Zagreb

Croatia 
